\title{
DURATION EFFECT FROM HUMAN CHORIONIC GONADOTROPHIN (hCG) INJECTION TO OOCYTE RETRIEVAL ON INTRACYTOPLASMIC SPERM INJECTION (ICSI) PERFORMANCE IN MICE
}

\author{
Nor Farizah, A.H., Rahman, M.M., Wan Khadijah, W.E. and Abdullah, R.B.* \\ ${ }^{*}$ Corresponding author: R.B. Abdullah, Animal Biotechnology-Embryo Laboratory (ABEL), Institute of \\ Biological Sciences, Faculty of Science, University of Malaya, 50603 Kuala Lumpur, Malaysia. Tel \& \\ fax: 603-7967-4366 \\ *E-mail: ramli@um.edu.my
}

\begin{abstract}
This study was conducted to compare the effect of duration from human chorionic gonadotrophin (hCG) injection to oocyte retrieval (13-15 h or 16-18 h) on intracytoplasmic sperm injection (ICSI) performance in mice. The mice were superovulated with 5 IU of pregnant mare's serum gonadotrophin (PMSG) and subsequently $5 \mathrm{IU}$ of hCG $48 \mathrm{~h}$ later via intraperitoneal (i.p.) injection. The oocytes were retrieved 13-15 $\mathrm{h}$ or 16-18 $\mathrm{h}$ after hCG administration. The number of ovulated oocytes showing the first polar body (PB 1; metaphase II indicating matured oocytes) were higher at 13-15 h compared to $16-18 \mathrm{~h}$ post-hCG injection (P < 0.05). Only oocytes with the PB1 were used for ICSI. All cleavage rates following ICSI were shown to be higher in oocytes retrieved at $13-15 \mathrm{~h}$ post-hCG compared to $16-18 \mathrm{~h}$ post-hCG injection $(\mathrm{P}<0.05)$. In conclusion, it is suggested that oocytes can be retrieved at $13-15 \mathrm{~h}$ post-hCG injection and longer duration may be detrimental for ICSI performance in mice.
\end{abstract}

\begin{abstract}
ABSTRAK Kajian ini telah dijalankan untuk membandingkan kesan tempoh suntikan dari human chorionic gonadotrophin (pos-hCG) ke perolehan oosit (13-15 jam atau 16-18 jam) ke atas prestasi suntikan sperma intrasitoplasma (ICSI) dalam mencit. Mencit telah disuperovulasi dengan 5 IU pregnant mare's serum gonadotrophin (PMSG) dan kemudian dengan 5 IU hCG jarak 48 jam secara suntikan intraperitoneum (i.p.). Oosit dipungut 13-15 jam atau 16-18 jam selepas sunitkan hCG. Bilangan oosit terovulasi diperolehi yang menunjukkan jasad kutub pertama (PB; metafasa II menunjukkan oosit matang) adalah lebih tinggi pada tempoh 13-15 jam berbanding dengan 16-18 jam suntikan pos-hCG $(\mathrm{P}<0.05)$. Hanya oosit dengan PB1 digunakan untuk ICSI. Semua kadar pembelahan selepas ICSI telah ditunjukkan lebih tinggi pada tempoh 13-15 jam berbanding dengan suntikan 16-18 jam pos-hCG $(\mathrm{P}<0.05)$. Kesimpulannnya, adalah dicadangkan bahawa oosit boleh dipungut pada tempoh suntikan 13-15 jam pos-hCG dan tempoh yang lebih panjang mungkin memnjejaskan prestasi ICSI dalam mencit.
\end{abstract}

(Keywords: Post-hCG, Oocyte post-maturity, Intracytoplsmic sperm injection, Mice)

\section{INTRODUCTION}

The quality of oocytes recovered following superovulation was affected by several factors such as dose and timing of gonadotrophin injection [1, $2]$, weight [3], age [3, 4] and strain of mice [5, 6]. Recently, the timing of gonadotrophin injection attracted the attention of many researchers. Most of researchers chose relevant length of interval at the range of 13-15 $\mathrm{h}$ for oocyte collection following the human chorionic gonadotrophin (hCG) injection such as $13 \mathrm{~h}$ [7], $14 \mathrm{~h}$ [8], $14.5 \mathrm{~h}$ [2]. These durations were mainly chosen because ovulation in mice generally starts after $11-12 \mathrm{~h}$ following the hCG injection [3].
Matured oocytes (metaphase II stage) should be fertilised within the optimal time for fertilisation, which may be different for different species such as in mice (8-12 h), rats (12-14 h), rhesus monkeys and humans $(<24 \mathrm{~h})$ [9]. The event of ovulation (first polar body extrusion or metaphase II stage) and fertilisation is optimal at 11-14 h, while the extrusion of second polar body occurred at $17-23 \mathrm{~h}$ following the hCG injection [3]. If the oocyte is not fertilised at the optimal stage, it will undergo a time-dependent deterioration in quality and this process is known as oocyte aging [10]. The overmatured oocytes will start having physical changes such as large perivetelline space and degeneration of the first polar body or deviation of the PB1 from the metaphase II spindle indicating that the oocyte was undergoing the aging process [11]. Since 
different researchers suggested different durations of post-hCG oocyte retrieval for ICSI procedure in mice, therefore it is necessary to conduct specific research in this regard under different conditions. Therefore, this study was carried out under local setting to evaluate the oocyte retrieval quality and the ability of embryo development of matured oocytes collected at different durations (13-15 $\mathrm{h}$ and 16-18 h) following the hCG injection and subsequent ICSI.

\section{MATERIAL AND METHODS}

\section{Oocytes retrieval}

The female ICR mice (8-10 week-old) were superovulated with injections of 5 IU of pregnant mare's serum gonadotrophin (PMSG) and 5 IU of hCG injected $48 \mathrm{~h}$ apart. Matured oocytes were retrieved $13-15 \mathrm{~h}$ or $16-18 \mathrm{~h}$ following the $\mathrm{hCG}$ injection at the ampulla of the oviduct. The retrieved oocytes were rinsed in HEPES Whitten Medium (HWM), denuded the cumulus by hyluronidase solution $(0.1 \%)$ and subsequently rinsed in HWM and Whitten medium (WM). The oocytes with presence of first polar body (metaphase II stage) were selected and transferred in droplets of $\mathrm{WM}$, and stored at $37^{\circ} \mathrm{C}$ in $5 \% \mathrm{CO}_{2}$ incubator for ICSI procedure.

\section{Sperm preparation}

The matured male mice (10-15 week-old) were sacrificed by cervical dislocation. Sperm were collected from the caudal epididymis and suspended in TYH medium [12] and allowed to capacitate for $60 \mathrm{~min}$ at room temperature before ICSI procedure.

\section{Intracytoplasmic sperm injection (ICSI)}

ICSI was performed immediately after oocyte retrieval. Briefly, a lid of small IVF petri dish (35 $\mathrm{mm}$ ) was allocated for three microdroplets: (i) sperm suspension microdroplet, (ii) $10 \%$ polyvinyl pyrolidone (PVP) microdroplet and (iii) oocyte microdroplet. Two microneedles (ICSI microneedle and holding microneedle) were aligned using a micromanipulator. ICSI procedure was started by aspirating the sperm from sperm suspension microdroplet and placed into $10 \%$ PVP microdroplet. The sperm movement was being slowed to ease the immobilisation through kinked the sperm tail using the spike of ICSI microneedle. The immobilised sperm were aspirated by ICSI microneedle from the tail first with the minimum amount of PVP. The sperm were injected into the oocyte ooplasm by puncturing the zona pellucida and oolema.

Subsequently, the ooplasm might be aspirated a bit into ICSI microneedle to make sure the membrane was broken. Then, it gently placed back the ooplasm together with sperm into the oocyte. After that, the ICSI microneedle was withdrawn from the oocyte carefully without any remaining sperm or cytoplasm inside the microneedle. The injected oocytes were rinsed and placed for $30 \mathrm{~min}$ inside the incubated WM and were activated with 0.02 $\mathrm{mM}$ of strontium chloride for $3 \mathrm{~h}$ before being cultured in $\mathrm{WM}$ for 9 days at $37.5^{\circ} \mathrm{C}$ under $5 \% \mathrm{CO}_{2}$ in humidified air. The embryos were evaluated for development at Days 2, 5, 7 and 9.

\section{Statistical analysis}

The quality of oocytes and embryo development between two different post-hCG injection durations were analysed using one-way Analysis of Variance (ANOVA) with the significance level at 5\%. The differences among the obtained means were determined using Duncan's Multiple Range Test (DMRT). These analyses were performed using SPSS (version 12.0, SPSS Inc., Chicago, IL, USA).

\section{RESULTS}

A total of 224 ovaries were obtained from 120 donor mice with total numbers of oocytes per ovary of $13.91(n=1557)$ and $13.57(n=1520)$ for $13-15 h$ and 16-18 $\mathrm{h}$ durations, respectively. The rest 16 ovaries were not stimulated. There were significant $(\mathrm{P}<0.05)$ differences of oocyte retrieved morphology between the $13-15 \mathrm{~h}$ and $16-18 \mathrm{~h}$ posthCG injection durations on percent of oocytes with PB1 and percent of oocytes without PB1 with values of 75.61 vs. $67.37 \%$ and 12.50 vs. $21.82 \%$, respectively (Table 1). However, no significant ( $\mathrm{P}$ $>0.05$ ) differences were observed for the percent of dysmorphic oocytes with the values of 11.88 vs. $10.76 \%$, respectively. The cleavage rates at 2-, 4-, 8 - and morula cell stages were significantly $(\mathrm{P}<$ $0.05)$ higher (67.95 vs. $57.02 \%, 53.51$ vs. $41.90 \%$, 39.40 vs. $22.21 \%$, and 14.83 vs. $9.77 \%$ ) at $13-15 \mathrm{~h}$ compared to $16-18 \mathrm{~h}$ duration, respectively.

The cleavage rates for $13-15 \mathrm{~h}$ or $16-18 \mathrm{~h}$ were decreased in all cases from early to the later stages of embryo development. 
Table 1. Number and percent (mean \pm SEM) of oocytes obtained through oviduct oocytes retrieval in mice

\begin{tabular}{lcccccc}
\hline $\begin{array}{c}\text { Post-hCG } \\
\text { duration }\end{array}$ & $\begin{array}{c}\text { Total } \\
\text { no. of } \\
\text { mice }\end{array}$ & $\begin{array}{c}\text { *Total } \\
\text { no. of } \\
\text { ovaries }\end{array}$ & $\begin{array}{c}\text { Total no. of } \\
\text { oocytes per } \\
\text { ovary }\end{array}$ & $\begin{array}{c}\text { Percent of } \\
\text { oocytes with } \\
\text { polar body }\end{array}$ & $\begin{array}{c}\text { Percent of } \\
\text { oocytes } \\
\text { without polar } \\
\text { body }\end{array}$ & $\begin{array}{c}\text { Percent of } \\
\text { dysmorphic } \\
\text { oocytes }\end{array}$ \\
\hline $13-15 \mathrm{~h}$ & 60 & 112 & $\begin{array}{c}13.91 \pm 0.61^{\mathrm{a}} \\
(\mathrm{n}=1557)\end{array}$ & $\begin{array}{c}75.61 \pm 1.64^{\mathrm{b}} \\
(\mathrm{n}=1208)\end{array}$ & $\begin{array}{c}12.50 \pm 1.55^{\mathrm{a}} \\
(\mathrm{n}=177)\end{array}$ & $\begin{array}{c}11.88 \pm 1.16^{\mathrm{a}} \\
(\mathrm{n}=173)\end{array}$ \\
$16-18 \mathrm{~h}$ & 60 & 112 & $\begin{array}{c}13.57 \pm 0.54^{\mathrm{a}} \\
(\mathrm{n}=1520)\end{array}$ & $\begin{array}{c}67.37 \pm 1.50^{\mathrm{a}} \\
(\mathrm{n}=1044)\end{array}$ & $\begin{array}{c}21.82 \pm 1.49^{\mathrm{b}} \\
(\mathrm{n}=336)\end{array}$ & $\begin{array}{c}10.76 \pm 1.24^{\mathrm{a}} \\
(\mathrm{n}=139)\end{array}$ \\
\hline $\begin{array}{l}\text { Average } \\
\text { (Total) }\end{array}$ & - & - & $\begin{array}{c}13.74 \pm 0.41 \\
(\mathrm{n}=3077)\end{array}$ & $\begin{array}{c}71.49 \pm 1.14 \\
(\mathrm{n}=2252)\end{array}$ & $\begin{array}{c}17.16 \pm 1.12 \\
(\mathrm{n}=513)\end{array}$ & $\begin{array}{c}11.32 \pm 0.85 \\
(\mathrm{n}=312)\end{array}$ \\
\hline
\end{tabular}

${ }^{*}$ Total no. of ovaries was based on ovaries that contained oocyte.

${ }^{a b}$ Mean values within a column with different superscripts were significantly different $(P<0.05)$.

SEM, standard error of the mean.

\section{DISCUSSION}

Earlier reports indicated that the quality of oocytes produced by superovulation was affected by several factors such as dose and timing of gonadotrophin injection [1, 2], weight [3], age [3, 4] and strain of mice $[5,6]$. Two groups of oocyte retrieval duration (13-15 $\mathrm{h}$ and 16-18 $\mathrm{h}$ ) were evaluated to determine their effects on the total numbers of oocytes per ovary which were 13.91 and 13.57 , respectively. There was no significant $(\mathrm{P}<0.05)$ difference in the number of oocytes retrieved between the two posthCG injection durations. However, percentage of $\mathrm{PB} 1$ present was significantly $(\mathrm{P}<0.05)$ higher in 13-15 h group (75.61\%) compared with 16-18 h group (67.37\%). Conversely, the percentage of oocytes without PB1 was significantly $(\mathrm{P}<0.05)$ lower in 13-15 $\mathrm{h}$ group $(12.50 \%)$ compared with 16-18 $\mathrm{h}$ group $(21.82 \%)$. This might be due to the aging of oocytes (post-maturity) at 16-18 h. Matured oocytes (metaphase II stage) should be fertilised within the window of optimal fertilisation, which may be different for different species such as in mice (8-12 h), rats $(12-14 \mathrm{~h})$, rhesus monkeys and humans $(<24 \mathrm{~h})$ [9]. The event of ovulation (PB1 or metaphase II stage) and fertilisation is optimal at 11-14 $\mathrm{h}$ in mice [3].

Table 2. Cleavage rate (mean \pm SEM) of ICSI derived embryos for different post-hCG duration in mice

\begin{tabular}{|c|c|c|c|c|c|}
\hline \multirow{2}{*}{$\begin{array}{l}\text { Post-hCG } \\
\text { duration }\end{array}$} & \multirow{2}{*}{$\begin{array}{l}\text { No. of injected } \\
\text { oocyte }\end{array}$} & \multicolumn{4}{|c|}{ Cleavage rate $(\%)$} \\
\hline & & 2-cell & 4-cell & 8-cell & Morula \\
\hline $13-15 \mathrm{~h}$ & 1208 & $\begin{array}{c}67.95 \pm 1.06^{b} \\
(n=836)\end{array}$ & $\begin{array}{c}53.51 \pm 1.13^{b} \\
(\mathrm{n}=662)\end{array}$ & $\begin{array}{c}39.40 \pm 1.01^{b} \\
(n=481)\end{array}$ & $\begin{array}{c}14.83 \pm 1.09^{b} \\
(\mathrm{n}=200)\end{array}$ \\
\hline $16-18 \mathrm{~h}$ & 1044 & $\begin{array}{c}57.02 \pm 1.33^{\mathrm{a}} \\
(\mathrm{n}=621)\end{array}$ & $\begin{array}{c}41.90 \pm 1.98^{\mathrm{a}} \\
(\mathrm{n}=468)\end{array}$ & $\begin{array}{c}22.21 \pm 1.62^{\mathrm{a}} \\
\quad(\mathrm{n}=251)\end{array}$ & $\begin{array}{c}9.77 \pm 1.02^{\mathrm{a}} \\
(\mathrm{n}=127)\end{array}$ \\
\hline $\begin{array}{l}\text { Average } \\
\text { (Total) }\end{array}$ & $\begin{array}{c}1126 \\
(\mathrm{n}=2252)\end{array}$ & $\begin{array}{c}62.56 \pm 1.05 \\
(\mathrm{n}=1457)\end{array}$ & $\begin{array}{c}47.78 \pm 1.31 \\
(\mathrm{n}=1130)\end{array}$ & $\begin{array}{c}30.92 \pm 1.37 \\
(\mathrm{n}=732)\end{array}$ & $\begin{array}{c}12.33 \pm 0.80 \\
(\mathrm{n}=327)\end{array}$ \\
\hline
\end{tabular}

*No. of injected oocytes was based on total no. of oocytes used for ICSI (MII stage).

${ }^{\mathrm{ab}}$ Mean values within a column with different superscripts were significantly different $(P<0.05)$.

SEM, standard error of the mean. 
In addition, if the oocytes are not fertilised within the fertilisation window, it will undergo a timedependent deterioration in quality. This process is known as oocyte aging [10]. The high percentage of oocytes without PB1 was found in 16-18 h posthCG injection duration. This might be due to the oocytes started undergoing physical changes such as larger perivetelline space and the PB1 either started to degenerate or deviate from the metaphase II spindle leading to the process of aging [11].

There were a few percentages of dysmorphic oocytes at both duration groups. Both duration groups (13-15 h and 16-18 h) showed no significant $(\mathrm{P}>0.05)$ difference in percentage of dysmorphic oocytes. The presence of dysmorphic oocytes may be due to the exposure with hyaluronidase enzyme during denuding process. Inappropriate or high concentration of hyaluronidase can activate the mouse oocytes [13]. In ICSI, the hyaluronidase concentration was reduced to $80 \mathrm{IU} / \mathrm{ml}$ to avoid activation, but for this case, the exposure duration of oocytes to this chemical might initiate the oocytes to be activated and became parthenotes or fragmented. Other than that, the DNA fragmentation could also occur in the first polar body and oocyte cytoplasm, indicating they were undergoing apoptotic changes [14]. Apoptosis is a morphological process that was caused by 'cellular suicide' programme. Degenerating oocytes with cytoplasmic fragmentation were frequently found at oocyte retrieval [15]. However, the reason for the occurrence of cytoplasmic fragmentation is still unclear [14].

Only the oocytes with presence of PB1 indicating matured oocytes were used for ICSI experiments. Oocytes without PB1 and dysmorphic oocytes were discarded to ensure only viable oocytes were used for ICSI procedure. This was because good quality oocytes would affect subsequent embryo development after fertilisation [16]. The embryo development cleavage rates at 2-, 4-, 8- and morula cell stages were significantly $(\mathrm{P}<0.05)$ higher at 13-15 $\mathrm{h}$ compared to $16-18 \mathrm{~h}$ duration, which clearly showed that the post-hCG injection duration ranging from 13-15 h gave better result for oocytes retrieval and embryo development through ICSI procedure. The oocyte aging as shown in this study (16-18 $\mathrm{h}$ duration) before fertilisation may cause low embryo development rates and also early pregnancy failure in several mammalian species [17]. Thus, the use of aged oocyte should be minimised or avoided in order to obtain good embryo development and pregnancy.

\section{CONCLUSIONS}

It can be inferred that duration ranging from $13-15 \mathrm{~h}$ post-hCG injection to oocyte retrieval could produce optimum ICSI performance in mice. Oocyte aging could have occurred when oocyte retrieval is carried out $16 \mathrm{~h}$ post hCG administration, resulting in poor embryo development after ICSI.

\section{ACKNOWLEDGEMENTS}

The authors would like to express thanks to all ABEL members for all supports during conducting this research. The authors would also like to thank University of Malaya for the financial support through Institute of Research Management and Consultancy of University Malaya, IPPP Grant (PS273/2009C).

\section{REFERENCES}

1. Edgar, D.H., Walley, K.M. and Mills, J.A. (1987). Effects of high-dose and multiple dose gonadotropin stimulation on mouse oocyte quality as assessed by preimplantation development following in vitro fertilization. Journal of In Vitro Fertilization and Embryo Transfer. 4:273276.

2. Vergara, G.J., Irwin, M.J., Moffatt, R.J. and Pinkert, C.A. (1997). In vitro fertilization in mice: strain differences in response to superovulation protocols and effects of cumulus cells removal. Theriogenology. 47:1245-1252.

3. Hogan, B., Constantini, F. and Lacy, E. (1986). Manipulating the Mouse Embryos. A Laboratory Manual. 1st edition. Cold Spring Harbor Laboratory. USA.

4. Ozgunen, K.T., Erdogan, S., Mazmanoglu, N., Pamuk, I., Logoglu, G. and Ozgunen, T. (2001). Effect of gonadotrophin dose on oocyte retrieval in superovulated BALB/c mice. Theriogenology. 56:435-445.

5. Goh, S.Y. (2008). Effect of strains of mice and their crossbreds on IVF performance. BSc Thesis. University of Malaya, Kuala Lumpur. 
6. Ainul Bahiyah, A.B. (2010). In vitro and in vivo developmental competence of intact, in vitro-derived and cryopreserved murine embryos. PhD Thesis. University of Malaya, Kuala Lumpur.

7. Hiller, S.G., Siddiquey, A.K.S. and Winston, R.M.L. (1985). Fertilization in vitro of cumulus-enclosed mouse oocytes: effect of timing of the ovulatory hCG injection. International Journal of Fertility and Sterility. 30:34-38.

8. Martin-Coello, J., Gonzalez, R., Crespo, C., Gomendio, M. and Roldan, E.R.S. (2008). Superovulation and in vitro oocyte maturation in three species of mice (Mus musculus, Mus spretus and Mus spicilegus). Theriogenology. 70:10041013.

9. Austin, C.R. (1974). Concept of development In: Whitter J.R. (ed.). Sineur Associates Inc., Publisher.

10. Miao, Y.L., Kikuchi, K., Sun, Q.Y. and Schatten, H. (2009). Oocyte aging: cellular and molecular changes, developmental potential and reversal possibility. Human Reproduction. 15:573-585.

11. Miao, Y., Ma, S., Liu, X., Miao, D., Chang, Z., Luo, M.J. and Tan, J. (2004). Fate of the first polar bodies in mouse oocytes. Molecular Reproduction and Development. 69:66-76.
12. Toyoda, Y., Yokoyama, M. and Hosi, T. (1972). Studies on the fertilization of mouse egg in vitro. I. In vitro fertilization of mouse eggs by fresh epididymal sperm. Japanese Journal of Animal Reproduction. 16:147-151.

13. Kaufman, M. (1983). Early mammalian development: parthenogenetic studies. Cambridge University Press, Cambridge, UK.

14. Fujino, Y., Ozaki, K., Yamamasu, S., Ito, F., Matsuoka, I., Hayashi, E., Nakamura, H., Ogita, S., Sato, E. and Inoue, M. (1996). DNA fragmentation of oocytes in aged mice. Human Reproduction. 11:1480-1483.

15. Wyllie, A.H. (1981). Cell death: a new classification separating apoptosis from necrosis. In: Cell Death in Biology and Pathology. Editors: Bowen, I.D. and R.A. Lockshm. Chapman \& Hall, New York. pp. 9-13.

16. Wang, W.H. and Sun, Q.Y. (2007). Evaluation of oocyte quality: morphological, cellular and molecular predictors. Reproduction, Fertility and Development.19:1-12.

17. Wilcox, A.J., Weinberg, C.R. and Baird, D.D. (1998). Post-ovulatory ageing of human oocyte and embryo failure. Human Reproduction. 13:394-397. 